\title{
Enhancement of Solar Water Desalination Using Copper and Aluminum Oxide Nanoparticles
}

\author{
Mohammad A. Hamdan ${ }^{1}$, Anas M. Al Momani ${ }^{1}$, Osama Ayadi ${ }^{1, *(D)}$, Ahmad H. Sakhrieh ${ }^{1,2}$ (1) \\ and Francisco Manzano-Agugliaro ${ }^{3, *(D)}$ \\ 1 Mechanical Engineering Department, The University of Jordan, Amman 11942, Jordan; \\ mhamdan@ju.edu.jo (M.A.H.); anas.mohamad88@yahoo.com (A.M.A.M.); \\ ahmad.sakhrieh@aurak.ac.ae (A.H.S.) \\ 2 Department of Mechanical and Industrial Engineering, American University of Ras Al Khaimah, \\ Ras Al Khaimah 10021, United Arab Emirates \\ 3 Department of Engineering, ceiA3, University of Almeria, 04120 Almeria, Spain \\ * Correspondence: o.ayadi@ju.edu.jo (O.A.); fmanzano@ual.es (F.M.-A.)
}

check for updates

Citation: Hamdan, M.A.; Al Momani, A.M.; Ayadi, O.; Sakhrieh, A.H.; Manzano-Agugliaro, F. Enhancement of Solar Water Desalination Using Copper and Aluminum Oxide Nanoparticles. Water 2021, 13, 1914. https:// doi.org/10.3390/w13141914

Academic Editor: Alexandros I. Stefanakis

Received: 2 June 2021

Accepted: 7 July 2021

Published: 10 July 2021

Publisher's Note: MDPI stays neutral with regard to jurisdictional claims in published maps and institutional affiliations.

Copyright: (C) 2021 by the authors. Licensee MDPI, Basel, Switzerland. This article is an open access article distributed under the terms and conditions of the Creative Commons Attribution (CC BY) license (https:// creativecommons.org/licenses/by/ $4.0 /)$.

\begin{abstract}
In this research, two identical solar stills were designed and constructed to investigate the effect of adding copper and aluminum oxide nanoparticles on the quantity of water produced by solar desalination. The two solar stills were installed side by side, and measurements were recorded simultaneously from both stills. The nanoparticles were added to one still, each at one time but with different concentrations, while the other contained only water. Data acquisition and a weather station were used to record the glass, water, and ambient temperatures in addition to the hourly solar radiation. It was found that the addition of nanoparticles increases the amount of condensate. The most efficient concentrations were found to be $0.4 \%$ of $\mathrm{Al}_{2} \mathrm{O}_{3}$ and $0.6 \%$ of $\mathrm{CuO}$. At these concentrations, an increase in the efficiency of the still equals $7.8 \%$, and $9.62 \%$ was recorded. Furthermore, it was found that $\mathrm{CuO}$ has a more pronounced effect on the condensate than $\mathrm{Al}_{2} \mathrm{O}_{3}$ at all concentrations except at $0.4 \%$ concentration.
\end{abstract}

Keywords: solar still; water desalination; nanofluids; solar energy

\section{Introduction}

Water security presents as one of the biggest global challenges. During the World Economic Forum in 2015, water was ranked first in terms of global risk, with the highest economic impact for the next decade [1]. This high importance of the water issue is closely reflected in the Sustainability Development Goals (SDGs), not only by mentioning the water goal as the sixth goal (SDG 6), but also by considering its effect on other goals of the development agenda [2]. In addition to that, the enormous growth in the global population and industrial development increases the pressure for clean water [3]. Simultaneously, deforestation activities resulted in a reduction in rainfall. Thus, a mismatch occurs between the supply and demand of clean water. The issue of clean water availability presents a central area of research for the time-being and the future.

The Earth contains about 1.4 billion cubic kilometers of water, covering about $70 \%$ of its surface, where $97.5 \%$ of this water is salty. Only $0.5 \%$ of the remaining freshwater is accessible to support life on earth [4]. Converting saline and impure water into drinkable water can be achieved by several methods, among which desalination is the most important. However, fossil fuels are the primary energy source used in desalination processes. The environmental impacts of such fuels are well-known [5]. On the other hand, solar distillation is one of the main techniques that utilize clean solar energy for freshwater production in sunny regions with insufficient or inadequate quality water resources [6]. In a solar desalination process, pure water is produced by separating salts from brackish water using a solar still, utilizing solar energy. Historically, the Arabian alchemists were 
the first to develop solar distillation to produce potable water using solar energy in the 16 th century [7].

The operation of solar stills mimics the natural cycle of water. Solar energy received by the water's surface delivers the required energy for water to evaporate, while salts and other minerals and impurities remain at the bottom; this water vapor then rises to condensate on the inner surface of the tilted transparent cover of the still where it is collected [8]. The single-basin, single-slope solar still presents the most straightforward design, leading to a low construction cost. However, it has very low water productivity [9].

Recently, researchers have been trying to enhance the performance of solar stills. The single-slope, single-basin still has been upgraded into different designs that result in higher yield: multi-basin [10], double-slope [11], weir-type [12], stepped [13], inverted trickle [14], and inclined $[15,16]$.

Gomir [17] showed that the double-effect absorption systems are more efficient than the single ones in energy and exergy. In contrast, the single effect is slightly better in terms of water production. Majeed et al. [18] modeled a solar desalination system in Basra that consists of a concentrating solar collector with a two-axis tracking system. The heat produced by the collector is delivered to two multi-effect distillation units. They found out that the productivity of the proposed desalination system was 5.3,6.4, 5.3, and $4.4 \mathrm{~m}^{3} /$ hour for the four months of March, June, September, and December, respectively. Moreover, the inclusion of a thermal fluid heat transfer process inside the absorber tubes improved the system's productivity.

In addition to the design of the solar still described earlier, researchers have also investigated the design of different top covers of the stills to improve their performance, where such designs have included that which are hemispherical [19], spherical [20], Vtype [21], triangular prism [22], pyramidal (triangular and square) [23], conical [24], and tubular [25]. The pyramid design of the cover of the solar still showed to be more efficient and economical in comparison to single slope still [26]. Thus, the pyramid top is used in this research.

From a thermal perspective, one of the main limitations of the efficiency of solar still applications is the low thermal conductivity of heat transfer fluids. Therefore, a different approach that researchers are investigating to enhance the operation of the solar still is to enhance the heat transfer of the water.

One way the heat transfer of the water is enhanced is by suspending ultra-fine solid particles in it. Nanofluids refer to the suspension of nano-sized particles in a base fluid. This term was first introduced by Choi in 1995 [27]. Since then, many researchers have theoretically and experimentally studied the effect of nanofluids on heat transfer efficiency in thermal engineering systems. Researchers have also tried different preparation techniques and models for the calculation of thermophysical properties of nanofluids.

The improved properties of heat-transfer fluids (HTF) with nanofluids encouraged researchers to investigate direct-absorption solar collectors (DACs), which was found to be more efficient than the indirect absorption applied in conventional solar collectors [28]. In [29], the authors experimentally investigated the thermal conductivity of different nanofluids. These nanofluids were copper oxide, zinc oxide, and aluminum oxide. The effect of the particle volumetric concentration was studied. The results indicated that the thermal conductivity of nanofluid compared to base fluid increases when the volumetric concentration of nanoparticles increases.

Mahian et al. reviewed the applications of nanofluids in solar energy applications [30]. Additionally, Gnanadason et al. [31] reported works on the applications of nanofluids in a modified vacuum single-basin solar still, and results showed that its productivity increased. Sindal et al. used $\mathrm{ZnO}$ nanoparticles as a photocatalyst. They concluded that productivity and the quality of the raw water increased to a remarkable extent [32].

Kabeel et al. studied the productivity of a typical single-slope solar still under vacuum conditions. They studied the performance of different concentrations of a mixture of $\mathrm{CuO}$ 
and $\mathrm{Al}_{2} \mathrm{O}_{3}$ nanofluids. They reported increased productivity by $93.87 \%$ and $88.97 \%$ when using $\mathrm{CuO}$ and $\mathrm{Al}_{2} \mathrm{O}_{3}$, respectively [33].

Hamdan and Drarabee investigated the effect of adding $\mathrm{TiO}_{2}$ and $\mathrm{Al}_{2} \mathrm{O}_{3}$ nanoparticles on the solar disinfection process of contaminated water. Six glass containers were used in their study, one of which is used as a reference unit. The other five containers contained contaminated water with a specific concentration of nanoparticles. The six containers were exposed side by side to solar radiation, and samples from each container were withdrawn to measure the total counts of both Coliform and E. Coli. Results showed that concentrations of $0.06 \%$ of both nanofluids are necessary to minimize the bacteria. In comparison, a higher concentration of about $0.1 \%$ is required to destroy all bacteria in the water samples. Moreover, they concluded that $\mathrm{TiO}_{2}$ has a quicker impact than $\mathrm{Al}_{2} \mathrm{O}_{3}$ [34].

Mutlq et al. conducted experiments on two identical roof-type solar stills installed side by side. The first one was tested under vacuum conditions, while the second was under atmospheric pressure conditions. Different concentrations $(0.2-0.6 \%)$ of $\mathrm{Al}_{2} \mathrm{O}_{3}$ were added to the water inside the evacuated still. It was found that the evacuated still produces $34.84 \%$ more than the reference still even without any nanofluids. In addition to that, it was found that the utilization of $0.4 \% \mathrm{Al}_{2} \mathrm{O}_{3}$ enhanced the production by $44.4 \%$ [35].

Pasra et al. compared the performance of solar stills at different altitudes with and without silver nanofluid, the city of Tehran (altitude of $1171 \mathrm{~m}$ ), and Mount Tochal (altitude of $4000 \mathrm{~m}$ ). The solar still at Mount Tochal with nanofluids was about double that at Tehran without nanofluids [36]. Singh et al. reviewed and summarized the modeling of solar desalination units with nanofluid. It was found that the solar desalination system with nanofluids produced more condensate than the conventional ones [37].

The authors in this study compared the performance (productivity) of a single-basin, square pyramid solar still with base fluid (water) and nanofluid $\left(\mathrm{Al}_{2} \mathrm{O}_{3}\right.$ and $\mathrm{CuO}$ nanoparticles) at five different concentrations of nanoparticles. Two identical stills were tested with water and different nanofluids simultaneously.

\section{Experimental Setup}

The experimental setup used in this study is shown in Figure 1. It consists of a basin solar still with an effective area of $0.16 \mathrm{~m}^{2}$, made of galvanized aluminum. A pyramid geometry glass cover was placed above the basin at a tilt angle of 47.1. The thickness of the glass is $6 \mathrm{~mm}$. The width and height of the pyramid triangle are $50 \mathrm{~cm}$ and $40 \mathrm{~cm}$. The dimensions of the basin of the solar still are shown in Figure 1. The entire assembly was made airtight with the help of a rubber gasket. The interior surfaces of both stills were painted black to ensure that the absorbed solar radiation would be the maximum possible, where hence, a higher temperature of nanofluid will be achieved. We hoped that this would not have an impact on the performance difference between $\mathrm{CuO}$ and $\mathrm{Al}_{2} \mathrm{O}_{3}$ because both stills were painted black, and measurements were conducted simultaneously.
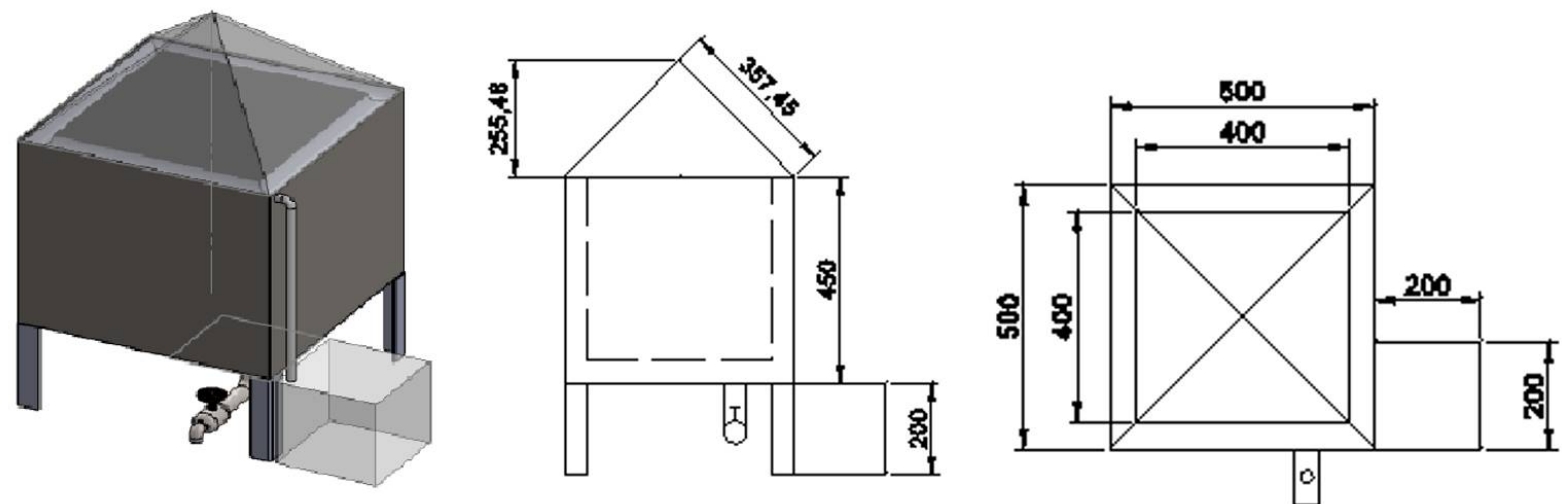

Figure 1. Schematic diagram for the solar still. 
The incident solar radiation was measured using a pyranometer which was connected to the data acquisition system. Ambient, glass, and water temperatures were measured using an LM35 temperature sensor connected to the data acquisition system.

Two solar stills were installed side by side in the Amman-Jordan ( $\left.31^{\circ} 57^{\prime} \mathrm{N}, 35^{\circ} 52^{\prime} \mathrm{E}\right)$. Jordan is blessed with very high solar radiation. The annual global solar radiation on the horizontal surface is about $2 \mathrm{MWh} / \mathrm{m}^{2}$.

At the beginning of the experiment, the height of the water was $12.5 \mathrm{~cm}$. Mainly two types of nanofluids were considered. These nanofluids are $30 \mathrm{~nm}$ aluminum oxide $\mathrm{Al}_{2} \mathrm{O}_{3}$ and $80 \mathrm{~nm}$ cupric oxide $\mathrm{CuO}$. They were compared to the condition where no nanoparticles were used with water. Different nanoparticle volume concentrations were tested $(0.2 \%$, $0.4 \%, 0.6 \%, 0.8 \%, 1 \%, 2 \%$, and $3 \%$ ). A stirrer was used for continuous mixing to ensure the homogeneity of the nanofluid.

The nanofluid was prepared by directly mixing the nanofluid with the base fluid. The amount of nanoparticles (with 50 nanometer size) required for the preparation of nanofluids was calculated using the law of the mixture formula. A sensitive balance with a $0.1 \mathrm{mg}$ resolution was used to weigh the nanoparticles. The mixture was thoroughly stirred continuously.

In this experiment, no surfactant was used, where to maintain the homogeneity of the nanofluid, a stirrer was used instead for continuous mixing, and in addition, very low concentrations of nanoparticles were used, where this was to make sure that the nanofluid was maintained homogenous during the work, which was ensured by visual inspection.

Volumetric production rates, solar radiation, ambient temperature, glass temperature, and water temperature were measured hourly. The readings were recorded on an hourly basis over $24 \mathrm{~h}$ from morning (9:00 a.m.) to the next day (9:00 a.m.). The experiments were repeated over three days to ensure the repeatability of the results. Regular cleaning for the salt deposition in the basin and dust on the top cover was implemented.

\section{Results and Discussion}

Volumetric production rates were obtained and compared to the condition where no nanoparticles were used with water. The difference between the volumetric production of the reference solar still and the solar still with $\mathrm{Al}_{2} \mathrm{O}_{3}$ is presented in Figure 2. It is clear that the addition of $\mathrm{Al}_{2} \mathrm{O}_{3}$ resulted in an increase in the volumetric production rate. The difference in production was highest when $0.4 \% \mathrm{Al}_{2} \mathrm{O}_{3}$ was added to water. The increase in the volumetric production increased sharply from $0.2 \%$ to $0.4 \% \mathrm{Al}_{2} \mathrm{O}_{3}$, reaching a maximum value of $43 \mathrm{~mL}$ at $0.4 \%$ concentration, beyond which it starts to decrease with an increase in the concentration of $\mathrm{Al}_{2} \mathrm{O}_{3}$. Furthermore, the addition of $0.4 \% \mathrm{Al}_{2} \mathrm{O}_{3}$ caused an increase in the efficiency of the solar still by a value of $7.8 \%$.

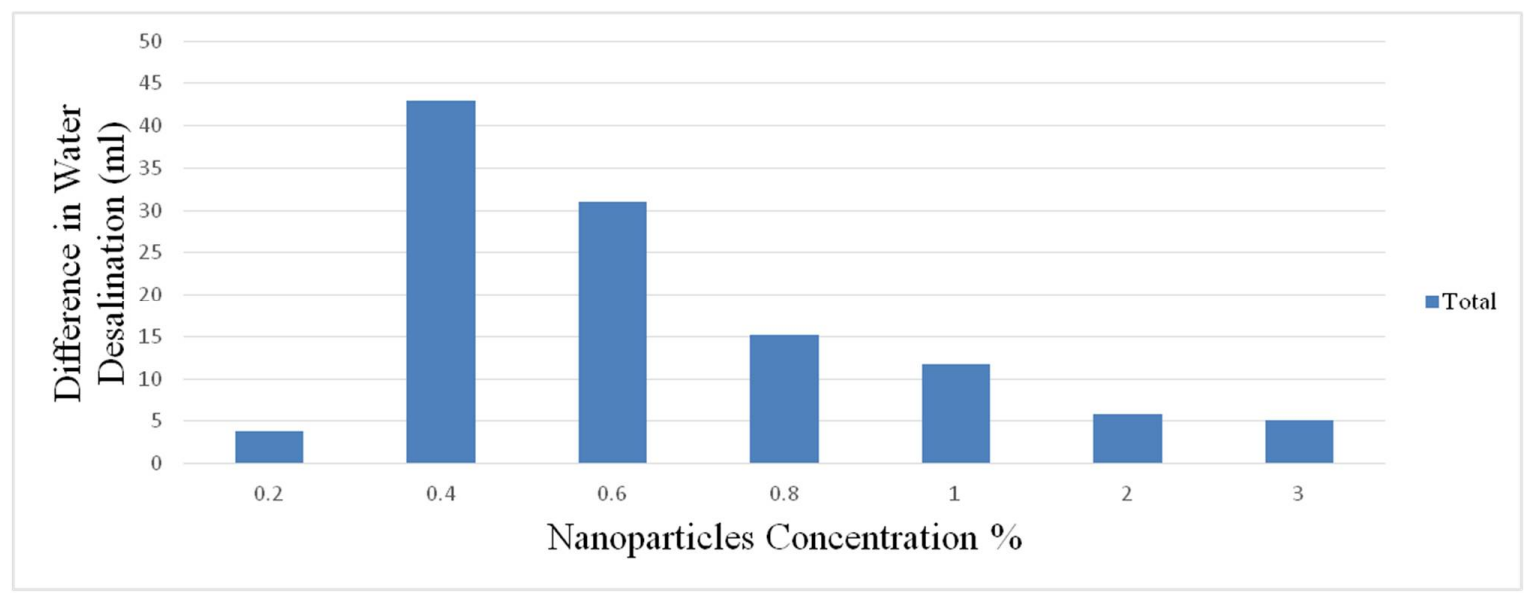

Figure 2. Effect of adding $\mathrm{Al}_{2} \mathrm{O}_{3}$ on the condensate. 
The hourly solar radiation, along with the water and glass temperatures, are presented in Figure 3. These parameters were measured during the same day when $0.4 \% \mathrm{Al}_{2} \mathrm{O}_{3}$ was added to water. The hourly solar radiation increases from zero during the night to a maximum value at noon, then decreases again to zero value after the sunset.

The volumetric production during the day is minor compared to the amount produced during the night because the temperature of the glass is higher than the temperature of the water during the day. During the night, the water temperature exceeds that of the glass. This enhances the evaporation process of the water and the volumetric production rate, as presented in Figure 4.

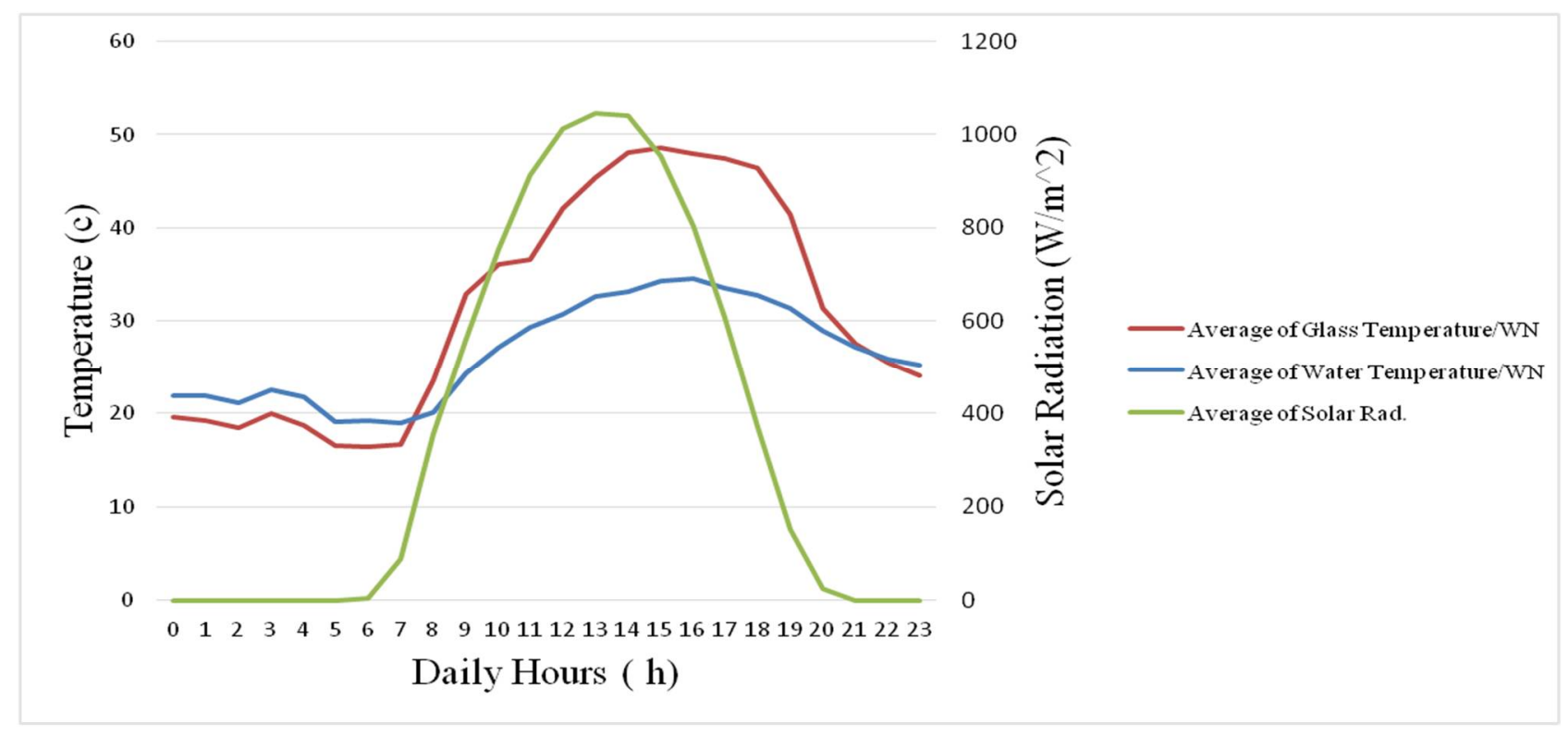

Figure 3. Hourly solar radiation and glass and water temperatures for $0.4 \%$ concentration of $\mathrm{Al}_{2} \mathrm{O}_{3}$.

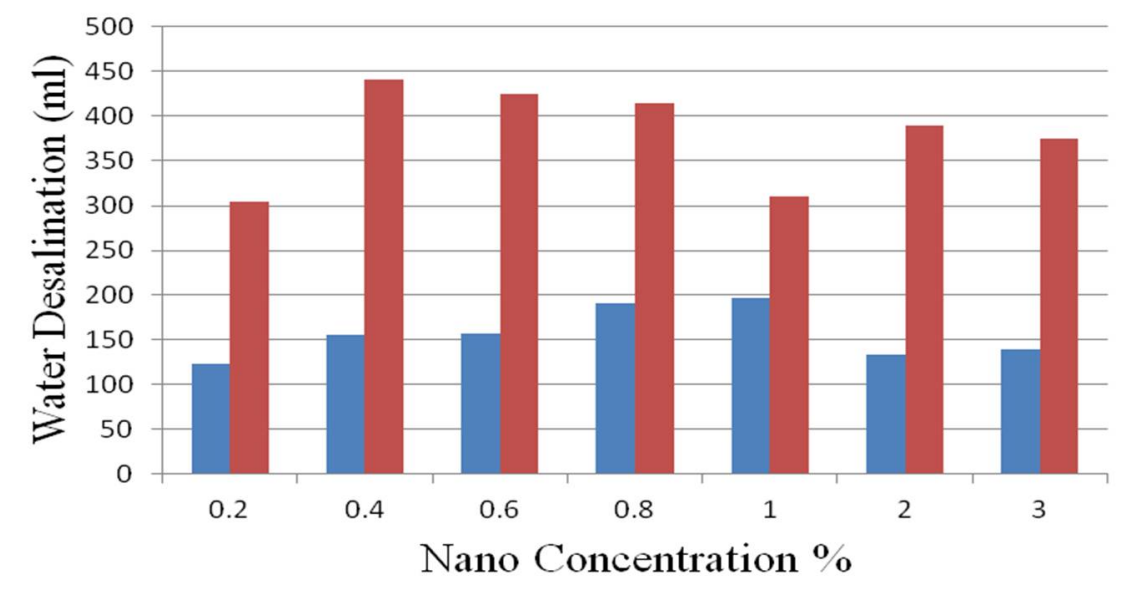

- During Day Time/WN

- During Night Time/WN

Figure 4. Effect of adding $\mathrm{Al}_{2} \mathrm{O}_{3}$ daily on the amount of condensate.

The same experiments were repeated using $\mathrm{CuO}$. Different $\mathrm{CuO}$ concentrations were used $(0.2 \%, 0.3 \%, 0.4 \%, 0.5 \%, 0.6 \%, 0.8 \%$, and $1.0 \%)$ and compared with the reference conditions where no nanoparticles were used with water. The difference between the volumetric production of the reference solar still and the solar still with $\mathrm{CuO}$ is presented 
in Figure 5. The maximum difference was found when $0.6 \% \mathrm{CuO}$ was added to water. The increase in the volumetric production increased gradually from $0.2 \%$ to $0.6 \% \mathrm{CuO}$, reaching a maximum value of $57.4 \mathrm{~mL}$ at $0.6 \%$ concentration, beyond which it starts to decrease with the concentration of $\mathrm{CuO}$. Furthermore, the addition of $0.6 \%$ of $\mathrm{CuO}$ caused an increase in the efficiency of the still by $9.62 \%$.

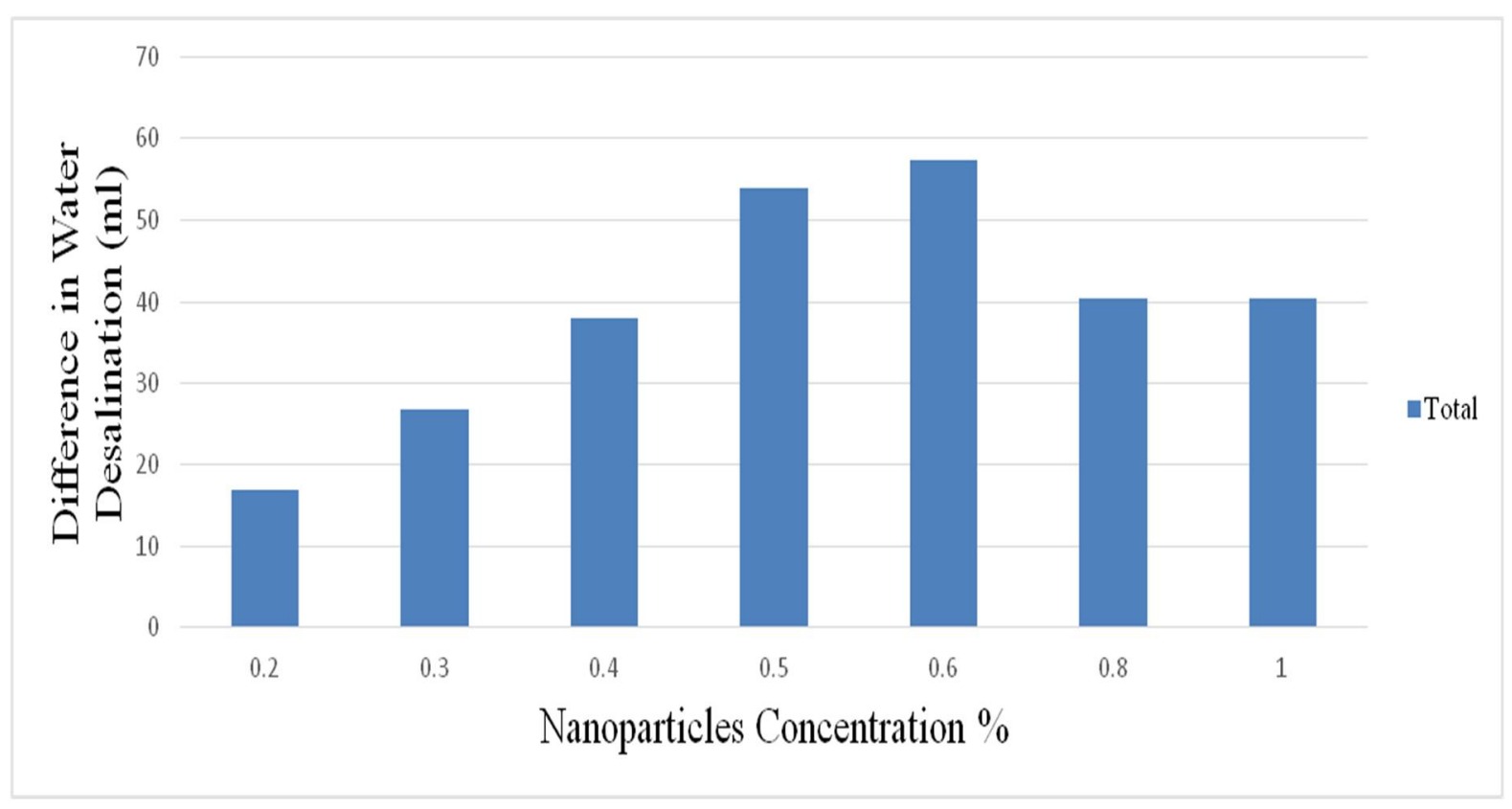

Figure 5. Effect of adding $\mathrm{CuO}$ on the condensate.

The hourly solar radiation along with the water and glass temperatures are presented in Figure 6. These parameters were measured during the same day when $0.6 \% \mathrm{CuO}$ was added to water. The hourly solar radiation increases from zero during the night to a maximum value at noon, then decreases again to zero value after the sunset.

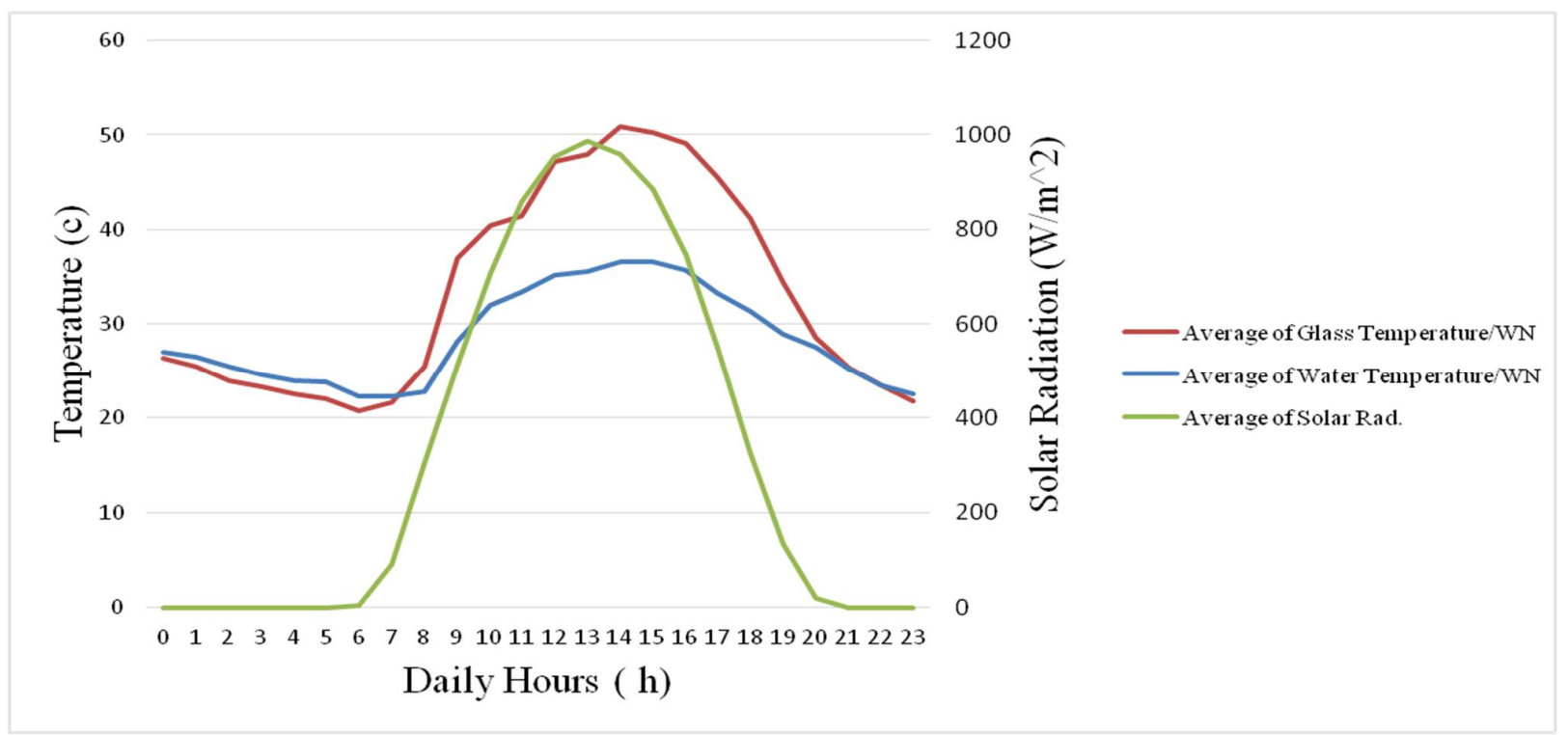

Figure 6. Hourly solar radiation and glass and water temperatures for $0.4 \%$ concentration.

Similarly, as in the case when $\mathrm{Al}_{2} \mathrm{O}_{3}$ was added, and during the daytime, the water temperature is less than that of the glass. This is reversed during the night. This leads to 
the fact that the amount of volumetric production during the day is minor compared to that during the night, as shown in Figure 7.

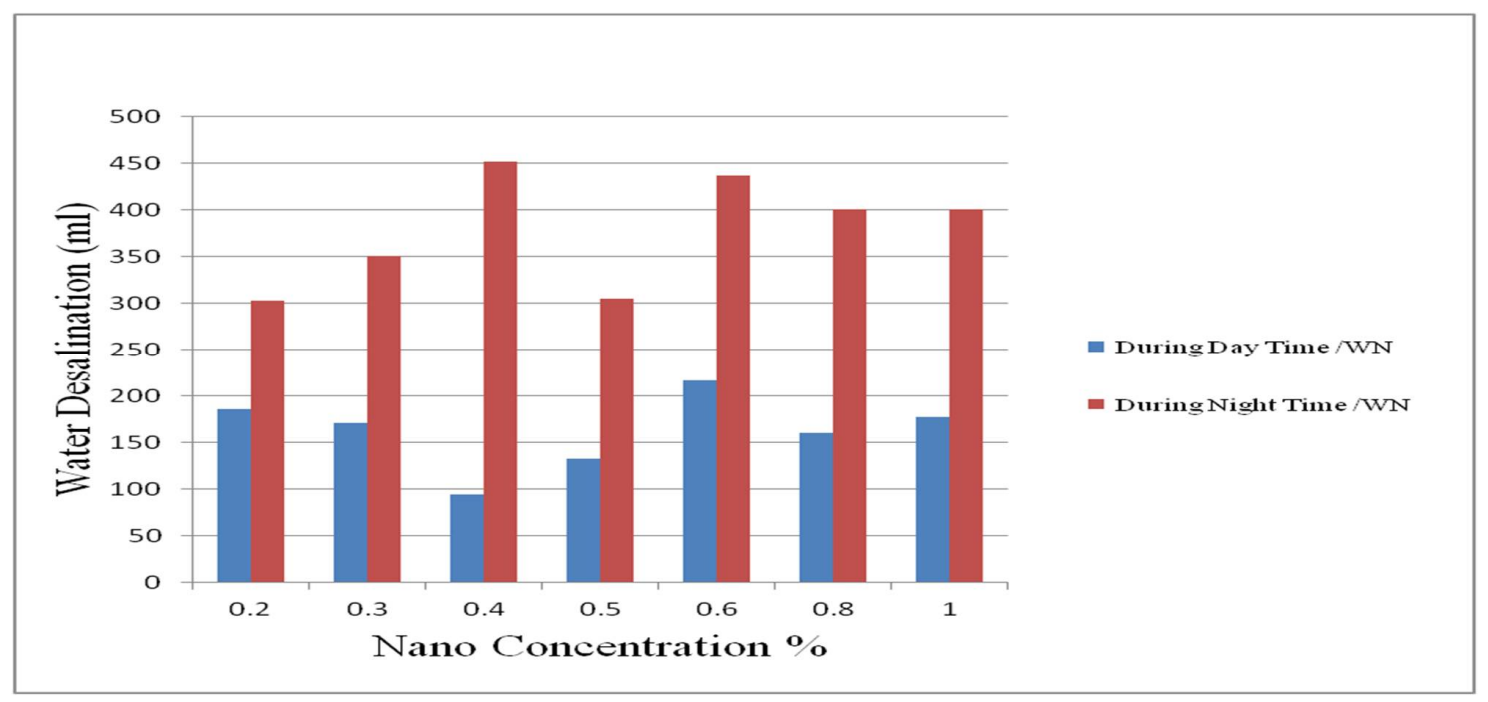

Figure 7. Effect of adding $\mathrm{CuO}$ daily on the amount of condensate.

As indicated in Figures 6 and 7, the condensate increases initially with the percentage concentration of both $\mathrm{CuO}$ and $\mathrm{Al}_{2} \mathrm{O}_{3}$ to maximum values, beyond which the amount of condensate starts to decrease. This decrease of production after a specific limit of the nanofluid concentration is because the more nanoparticles that exist, the more thermal energy is required to heat the nanoparticles; thus, less thermal energy is transferred to the base fluid, and condensate production is decreased.

As indicated in Figure 8, the $\mathrm{CuO}$ nanoparticle has a more pronounced effect on the increased quantity of condensate than that of $\mathrm{Al}_{2} \mathrm{O}_{3}$ at almost all concentrations. The thermal conductivity of $\mathrm{CuO}$ exceeds that of $\mathrm{Al}_{2} \mathrm{O}_{3}$, which leads to more thermal energy absorption by the $\mathrm{CuO}$ nanofluid compared with that absorbed by $\mathrm{Al}_{2} \mathrm{O}_{3}$, and hence, more condensate was produced. However, at $0.4 \%$ concentration of both types of particles, the effect of $\mathrm{Al}_{2} \mathrm{O}_{3}$ slightly exceeds that of $\mathrm{CuO}$. This is because at this concentration, the $\mathrm{Al}_{2} \mathrm{O}_{3}$ of nanoparticles yields the maximum amount of condensate, as stated previously.

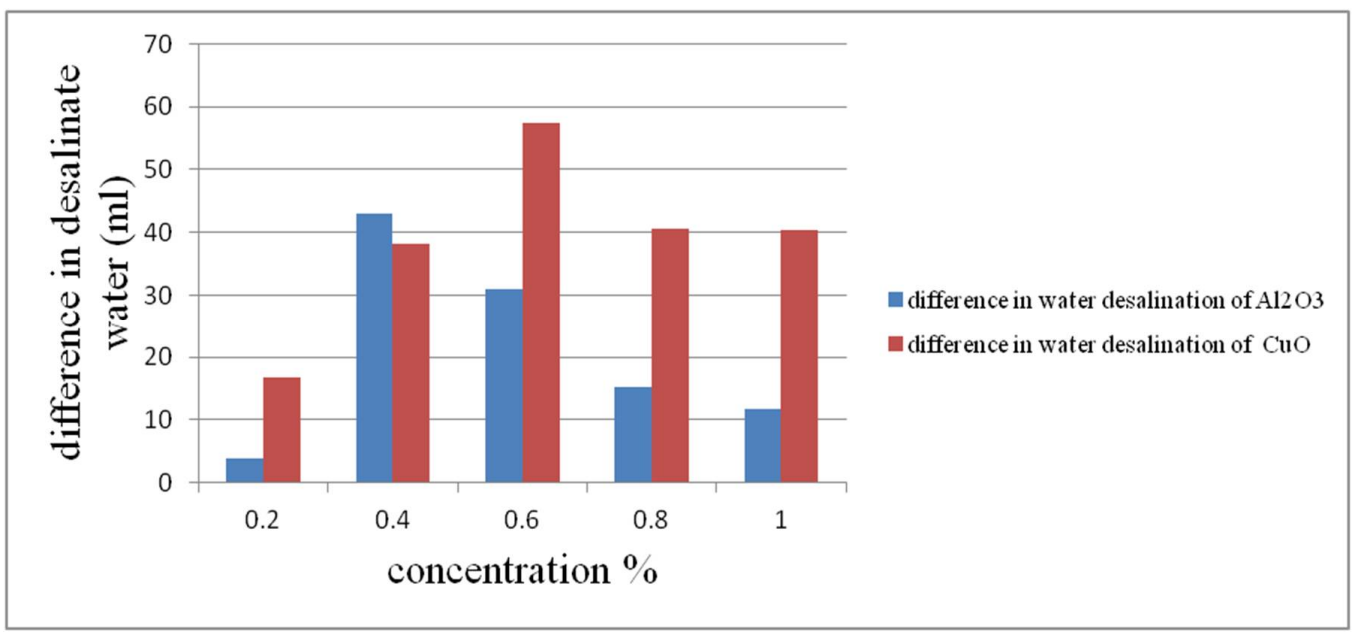

Figure 8. Effect of adding nanoparticles on the increased amount of condensate. 


\section{Economic Analysis}

Economic viability is the most crucial criterion that determines the success of a project. Several factors affect the unit cost of desalinated water using solar energy: unit size, solar radiation at the given location, quality of feed water, and the quality requirements of the final product [23].

In Table 1, the cost of components is described. The life expectancy of the setup is assumed to be 10 years. A water depth of $12.5 \mathrm{~cm}$ in the basin was used to do the economic analysis. All experiments were carried out in Amman, Jordan. The accumulated distillate of water with and without adding nanoparticles were $2.8125,2.45625 \mathrm{~L} /\left(\mathrm{m}^{2}\right.$.day), respectively. Table 2 was established to determine the total cost per liter of fresh water by using equations from Equations (1)-(3), which were introduced by Fath et al. [23]:

$$
\mathrm{TC} / \mathrm{L}=\text { Annual total cost } / \text { Total annual freshwater productivity }
$$

where TC/L is the total cost per liter of freshwater. The total annual cost is calculated according to equation

$$
\mathrm{ATC}=\mathrm{AFC}+\mathrm{AOMC},
$$

where ATC is the annual total cost, AFC is the annual fixed cost, and AMOC is the annual maintenance and operating cost that is calculated using equation

$$
\mathrm{AOMC}=30 \% \mathrm{AFC} \text {. }
$$

Table 1. The cost of the fabricated solar still.

\begin{tabular}{ccc}
\hline Material Unit & $\begin{array}{c}\text { Cost of Conventional Solar } \\
\text { Still [\$] }\end{array}$ & $\begin{array}{c}\text { Cost of Modified Solar Still } \\
\text { with Nanoparticles [\$] }\end{array}$ \\
\hline galvanized steel sheet (1.25 & 80 & 80 \\
mm thick) & 20 & 20 \\
Glass cover & 5 & 5 \\
Paints & 10 & 10 \\
Insulation & 10 & 10 \\
Support legs & 30 & 30 \\
Fabrication cost & - & 45 \\
Nanoparticles & 155 & 200 \\
Total fixed costs (F) & &
\end{tabular}

Table 2. Economic analysis of the proposed desalination system.

\begin{tabular}{ccc}
\hline & $\begin{array}{c}\text { without } \\
\text { Nanoparticles }\end{array}$ & with CuO Nanoparticles \\
\hline Initial Cost $(\$)$ & 155 & 200 \\
Annual Cost $(\$)$ & 15.5 & 20.0 \\
Maintenance and Operating cost $(\$)$ & 4.65 & 6.0 \\
Annual Total Cost $(\$)$ & 20.15 & 26 \\
Water production $\left(\mathrm{L} \cdot \mathrm{m}^{2} / \mathrm{y}\right)$ & 736.125 & 843.75 \\
Total cost per liter of fresh water, \$/L & 0.0274 & 0.0308 \\
\hline
\end{tabular}

Although water production was increased by adding nanoparticles, the total cost per liter of produced freshwater was higher compared with the basic setup without the addition of nanoparticles. Consequently, the cost of nanoparticles needs to be reduced. The high annual total cost for a modified still with nanoparticles is compensated by high annual water production.

\section{Conclusions}

Water productivity in a solar still can be improved with nanoparticles, such as $\mathrm{Al}_{2} \mathrm{O}_{3}$ and $\mathrm{CuO}$. The optimum concentrations of $\mathrm{Al}_{2} \mathrm{O}_{3}$ and $\mathrm{CuO}$ that yield maximum water 
volumetric production are $0.4 \%$ and $0.6 \%$, respectively. $\mathrm{CuO}$ has a more pronounced effect on the amount of condensate compared with that of $\mathrm{Al}_{2} \mathrm{O}_{3}$. The addition of $0.4 \% \mathrm{Al}_{2} \mathrm{O}_{3}$ and $0.6 \%$ of $\mathrm{CuO}$ causes an increase in the efficiency of the still that equals $7.8 \%$ and $9.62 \%$, respectively. Adding nanoparticles increased water production, but the per-liter cost of the produced freshwater was higher than the basic setup.

Author Contributions: Conceptualization, M.A.H. and A.M.A.M.; Literature review, O.A.; methodology, M.A.H.; Experimental work, A.M.A.M.; Data Analysis, M.A.H. and A.M.A.M.; Economical analysis, A.H.S.; writing—original draft preparation, M.A.H. and A.M.A.M.; writing—review and editing, F.M.-A.; All authors have read and agreed to the published version of the manuscript.

Funding: This work was funded by the Deanship of scientific research at the University of Jordan.

Institutional Review Board Statement: Not applicable.

Informed Consent Statement: Not applicable.

Data Availability Statement: Not applicable.

Conflicts of Interest: The authors declare no conflict of interest.

\section{References}

1. Sadoff, C.W.; Hall, J.W.; Grey, D.; Wiberg, D. Securing Water, Sustaining Growth. Available online: https://www.gwp. org/globalassets/global/about-gwp/publications/the-global-dialogue/securing-water-sustaining-growth.pdf (accessed on 16 September 2020).

2. General Assembly of the United Nations, Transforming Our World: The 2030 Agenda for Sustainable Development. Available online: https:/ / sdgs.un.org/2030agenda (accessed on 16 September 2020).

3. Goh, P.S.; Ismail, A.F.; Hilal, N. Nano-enabled membranes technology: Sustainable and revolutionary solutions for membrane desalination? Desalination 2016, 380, 100-104. [CrossRef]

4. El-Dessouky, H.T.; Ettouney, H.M. Fundamentals of Salt Water Desalination; Elsevier: Amsterdam, The Netherlands, 2002.

5. Fath, H.E.S. Solar distillation: A promising alternative for water provision with free energy, simple technology and a clean environment. Desalination 1998, 116, 45-56. [CrossRef]

6. Al-Hayeka, I.; Badran, O.O. The effect of using different designs of solar stills on water distillation. Desalination 2004, 169, 121-127. [CrossRef]

7. Cooper, P.I. Solar Distillation: State of the Art and Future Prospects. Available online: http://www.worldcat.org/title/solarenergy-and-the-arab-world/oclc/9895277 (accessed on 16 September 2020).

8. Sahooa, B.B.; Sahoob, N.; Mahantab, P.; Borboraa, L.; Kalitaa, P.; Sahab, U.K. Performance assessment of a solar still using blackened surface and thermocol insulation. Renew. Energy 2008, 33, 1703-1708. [CrossRef]

9. Velmurugan, V.; Gopalakrishnan, M.; Raghu, R.; Srithar, K. Single basin solar still with fin for enhancing productivity. Energy Convers. Manag. 2008, 49, 2602-2608. [CrossRef]

10. Shatat, M.I.M.; Mahkamov, K. Determination of rational design parameters of a multi-stage solar water desalination still using transient mathematical modelling. Renew. Energy 2010, 35, 52-61. [CrossRef]

11. Aburideh, H.; Deliou, A.; Abbad, B.; Alaoui, F.; Tassalit, D.; Tigrine, Z. An experimental study of a solar still: Application on the sea water desalination of Fouka. Procedia Eng. 2012, 33, 475-484. [CrossRef]

12. Sadineni, S.B.; Hurt, R.; Halford, C.K.; Boehm, R.F. Theory and experimental investigation of a weir-type inclined solar still. Energy 2008, 33, 71-80. [CrossRef]

13. Omara, Z.M.; Kabeel, A.E.; Younes, M.M. Enhancing the stepped solar still performance using internal and external reflectors. Energy Convers. Manag. 2014, 78, 876-881. [CrossRef]

14. Badran, A.A.; Assaf, L.M.; Kayed, K.S.; Ghaith, F.A.; Hammash, M.I. Simulation and experimental study for an inverted trickle solar still. Desalination 2004, 164, 77-85. [CrossRef]

15. Elango, T.; Kannan, A.; Murugavel, K.K. Performance study on single basin single slope solar still with different water nanofluids. Desalination 2015, 360, 45-51. [CrossRef]

16. Sahota, L.; Tiwari, G.N. Effect of nanofluids on the performance of passive double slope solar still: A comparative study using characteristic curve. Desalination 2016, 388, 9-21. [CrossRef]

17. Gomri, R. Seawater Desalination System Integrated to Single Effect and Double Effect Absorption Heat Transformers. Jordan J. Mech. Ind. Eng. 2010, 4, 217-224.

18. Majeed, A.J.; Mohammed, G.J.; Abdulrazaqc, A. Sustainable Energy for Water Desalination System Relative to Basra Climate. Jordan J. Mech. Ind. Eng. 2015, 9, 129-137.

19. Arunkumar, T.; Jayaprakash, R.; Denkenberger, D.; Ahsan, A.; Okundamiya, M.S.; Kumar, S.H.; Tanaka, H.; Aybar, H.S. An experimental study on a hemispherical solar still. Desalination 2012, 286, 342-348. [CrossRef]

20. Dhiman, N.K. Transient analysis of a spherical solar still. Desalination 1998, 69, 47-55. [CrossRef] 
21. Kumar, B.S.; Kumar, S.; Jayaprakash, R. Performance analysis of a "V" type solar still using a charcoal absorber and a boosting mirror. Desalination 2008, 229, 217-230. [CrossRef]

22. Wassouf, P.; Peska, T.; Singh, R.; Akbarzadeh, A. Novel and low cost designs of portable solar stills. Desalination 2011, 276, 294-302. [CrossRef]

23. Fath, H.E.S.; El-Samanoudy, M.; Fahmy, K.; Hassabou, A. Thermal-economic analysis and comparison between pyramid-shaped and single-slope solar still configurations. Desalination 2003, 159, 69-79. [CrossRef]

24. Gad, H.E.; Shams El-Din, S.; Hussien, A.A.; Ramzy, K. Thermal analysis of a conical solar still performance: An experimental study. Sol. Energy 2015, 122, 900-909. [CrossRef]

25. Kumar, A.; Anand, J.D. Modelling and performance of a tubular multi-wick solar still. Energy 1992, 17, 1067-1071. [CrossRef]

26. Nayi, K.H.; Modi, K.V. Pyramid solar still: A comprehensive review, Renew. Sustain. Energy Rev. 2018, 81, 136-148. [CrossRef]

27. Choi, S.U.S.; Eastman, J.A. Enhancing thermal conductivity of fluids with nanoparticles. ASME-Publications-Fed. 1995, 231, 99-106.

28. Delfani, S.; Karami, M.; Behabadi, M.A.A. Performance characteristics of a residential-type direct absorption solar collector using MWCNT nanofluid. Renew. Energy 2016, 87, 754-764. [CrossRef]

29. Vajjha, R.S.; Das, D.K. Experimental determination of thermal conductivity of three nanofluids and development of new correlations. Int. J. Heat Mass Transf. 2009, 52, 4675-4682. [CrossRef]

30. Mahian, O.; Kianifar, A.; Kalogirou, S.A.; Pop, I.; Wongwises, S. A review of the applications of nanofluids in solar energy. Int. J. Heat Mass Transf. 2013, 57, 582-594. [CrossRef]

31. Gnanadason, M.K.; Kumar, P.S.; Jemilda, G.; Jasper, S.S. Effect of nanofluids in a modified vacuum single basin solar still. Int. J. Sci. Eng. Res. 2012, 3, 2229-5518.

32. Sindal, M.; Singh, N.; Sharma, A. Solar desalination using zinc oxide as photocatalyst. J. Chem. Biol. Phys. Sci. $2013,3,958$.

33. Kabeel, A.E.; Omara, Z.M.; Essa, F.A. Improving the performance of solar still by using nanofluids and providing vacuum. Energy Convers. Manag. 2014, 86, 268-274. [CrossRef]

34. Hamdan, M.; Darabee, S. Enhancement of Solar Water Disinfection using Nanotechnology. Int. J. Therm. Environ. Eng. 2017, 15, 111-116.

35. Mutlq, E.; Hamdan, M.; Al Asfar, J. Enhancing the Productivity of a Roof-Type Solar Still Utilizing Alumina Nanoparticles and Vacuum Pump. J. Ecol. Eng. 2019, 20. [CrossRef]

36. Parsa, S.M.; Rahbar, A.; Koleini, M.H.; Javadi, Y.D.; Afrand, M.; Rostami, S.; Amidpour, M. First approach on nanofluid-based solar still in high altitude for water. Desalination and solar water disinfection (SODIS). Desalination 2020, 491, 114592. [CrossRef]

37. Singh, A.K.; Singh, D.B.; Dwivedi, V.K.; Tiwari, G.N.; Gupta, A. Water purification using solar still with/without nano-fluid: A review. Mater. Today Proc. 2020, 21, 1700-1706. [CrossRef] 